\title{
Életminőség, akadályozottság pszichiátriai diagnózissal ${ }^{1}$
}

\author{
BÁNYAI BORBÁLA
}

\begin{abstract}
ABSZTRAKT
A tanulmány célja a pszichiátriai diagnózissal, illetve akadályozottsággal élők életminőségének bemutatása. Az akadályozottsággal élők életminőségének bemutatása kvantitatív adatokra támaszkodik, a 2014-es European Social Survey standard és Egészséggel kapcsolatos egyenlőtlenség modulján alapul. A pszichiátriai diagnózissal élők életminőségének sajátosságait kvalitatív eszközök (narratív életútinterjú) segítségével ismertetem. A kutatások eredményei szerint azok az emberek, akik saját magukról úgy gondolják, hogy egészségi állapotuk miatt akadályozottsággal élnek, elsősorban az érzelmi és testi szubjektív jól-lét indikátoraiban mutatnak jelentős eltérést a nem akadályozott populációtól. A narratív interjúk elemzésének eredménye, hogy a pszichiátriai diagnózissal élők életminôségét alapvetően befolyásolja az általuk kialakított alkalmazkodási és megküzdési stratégia, mely azt a cél szolgálja, hogy mentális állapotuk és életük kiegyensúlyozott maradhasson.
\end{abstract}

KULCSSZAVAK: életminőség, általános jól-lét, akadályozottság, pszichiátriai diagnózissal élők, kvalitatív-kvantitatív kutatásmódszertan

\section{ABSTRACT}

\section{Quality of life, disability of people living with psychiatric diagnosis}

The paper aims at demonstrating the quality of life of the people living with psychiatic diagnosis. I used the data stemming from the standard and specific module (Social Inequalities in Health Quality) of the European Social Survey to present the quality of life of the disabled persons. I applied qualtitative methodology to investigate specifities of life course in case of people living with psychiatric diagnosis. My results suggest that people defining themselves as 'disabled' differ from non-hampered population first of all in the indicators of emotional and physical subjective well-being. According to the narrative interviews the quality of life of people living with psychiatric diagnose is largely influenced by their adaptive and coping strategies aiming to preserve the balance of their mental status.

KEYWORDS: Quality of life, well-being, people with disability, people living with psychiatric diagnosis, kvalitativ and kvantitative research method

${ }^{1}$ A kutatást a Nemzeti Kutatási és Innovációs Hivatal posztdoktori pályázata (PD_121202) támogatta.

${ }^{2}$ Egyetemi adjunktus, ELTE, Bárczi Gusztáv Gyógypedagógiai Kar. 


\section{TEMATIKUS TANULMÁNYOK - Pszi-komplexum}

\section{Bevezető}

A szubjektív jóllét mellett a nemzetközi szakirodalomban az 1980-as évek közepén megjelent az egyének életminőségének kutatása, elsősorban az oktatás, a gyógypedagógiai oktatás (special education), az egészségügy, a családkutatás, a szociális ellátórendszer (aging) területén (Schalock - Verdugo 2002). Ezek a kutatások általánosságban az emberek hétköznapi szükségleteinek teljesülését, a saját életükre vonatkozó döntési lehetőségeiket, az életüket meghatározó területek megváltoztatásának vagy javításának lehetőségét vizsgálják. Az életminőség modell kidolgozója Dr. Robert Schalock szerint az életminőség központjában (elméleti és kutatási szempontból is) magának az egyénnek kell állnia, és ez az elv megfeleltethető a „Semmit rólunk nélkülünk!" jelmondat tartalmával is. Az életminőségben megfogalmazott elvek támogatják az egyének egyenlőségét, amely reflektál az önmeghatározásra, az emancipációra, inklúzióra és az önérvényesítési képességre (Morris et al. 2013).

Feltehetően az egyéni szempontok figyelembevétele miatt is ez a kutatási és elméleti keret teret nyert a fogyatékossággal élő emberekkel kapcsolatos gondolkodásban is. Az életminőség területén ugyanis nem kizárólag a fogyatékosságból származó hátrányok jelennek meg, hanem az egyének életében jelen lévő egyéb adottságok, az egyének és a környezet kapcsolatában rejlő lehetőségek is. Az életminőség vizsgálatok további hozadéka, hogy nem pusztán kutatói, leíró célzattal készülnek, hanem egyéni és közösségi fejlesztési stratégiák alapjául is szolgálhat. Az életminőség vizsgálatok a fogyatékosságtudomány területén belül tehát a fejlesztési lehetőségek, cselekvési tervek kidolgozása felé is orientálódhatnak, nem pusztán a diszciplínán belül megszokott akadályozottság-akadálymentesítés terminusok által kijelölt keretre szorítkozik. Ennek következtében az életminőség modellje a fogyatékossággal élők életét jelentősen befolyásolhatja, mert megjelenhet a tudományos kutatások, a gyakorlatok és a szakpolitika szintjén is.

A következőkben bemutatom az életminőség fogalmának koncepcióját és meghatározását, majd ismertetem Schalock és társai-féle életminőség modellt. Magyarországon a pszichiátriai betegnek diagnosztizáltak a jogszabályokban nem szerepeltek külön fogyatékos kategóriaként a magas prevalencia ellenére sem, egészen 2013-ig (2013. évi LXII. törvény a fogyatékos személyek jogairól és esélyegyenlőségük biztosításáról szóló 1998. évi XXVI. törvény módosításáról), amikor kiegészítették a törvényt a pszichoszociális károsodással élők kategóriával. A mentális problémák kapcsán, a „betegség” sajátos természetéből fakadóan azonban nehezen megfogalmazható, mit is jelent az akadályozottság, az akadálymentesítés, esélyegyenlőség, diszkrimináció, társadalmi részvétel. Az erre vonatkozó hazai jogszabályi harmonizációra születtek már kísérletek, de szükségesnek tartom ezt kiegészíteni, ezért röviden ismertetem általában az akadályozottság fogalmát is. Tanulmányom célja, hogy bemutassam a pszichiátriai diagnózissal élők életminőségének sajátosságait, melyekhez kvantitatív és kvalitatív eszközöket is alkalmazok. 


\section{TEMATIKUS TANULMÁNYOK - Pszi-komplexum}

\section{Az életminőség meghatározása}

\section{I.1. AZ ÉLETMINŐSÉG KONCEPCIÓJA}

Az életminőség (Quality of Life? Quality of life (QoL)) egy komplex, multidimenziós fogalom, melynek gyökerei a nyugati filozófiából erednek, és ez a hagyomány a modern egészség és társadalomtudományi irodalomban folytatódik (Schalock - Verdugo 2002). Az az alapvető kérdés, hogy miért és minek hatására boldog egy ember, illetve, hogy az emberek jól-léte milyen elemekből áll, már Platónt és Arisztotelészt is foglalkoztatták (Rapley 2003). Az életminőség-modell jelentőségének megértéséhez szükséges tisztázni a szemantikai jelentését: az élet ebben az esetben az emberi élet alapvető lényegét jelenti, míg a minőségi minden olyan dolgot, ami pozitív lehet az ember életében, úgymint boldogság, siker, egészség, megelégedettség (Schalock - Verdugo 2002). Az egyén életét és annak minőségét befolyásoló számtalan tényező miatt vált ez a koncepció népszerúvé azokon a területeken, amely az egyén életminőségére közvetlenül hatással lehet (család, iskola, szociális szolgáltatások, szakpolitikák és gyakorlatok). Az elmélet többszempontú perspektívájának köszönhető, hogy az 1990-es évek közepétől az idézettsége megnőtt. Ennek több oka is van: a vizsgált területek és indikátorok is multidimenzionalitást biztosítanak, módszertani pluralizmus jellemzi, azaz a szubjektív és az objektív szempontok is érvényesülnek, a mikro-, mezo- és a makrorendszerek is megjelennek benne, biztosítja a kutatási design kialakításában és a kivitelezésben az érintettek részvételét, valamint a környezet és emberek sokfélesége is teret nyerhet (Schalock - Verdugo 2002).

A modell általános érvényesíthetőségét Schalock és társai kutatásai során több európai, ázsiai és amerikai országban is tesztelték (lásd Keith 1996, Keith - Schalock 2000, Markus - Kitayama 1991). Szemantikus differenciál skálát alkalmaztak, így az egyes területek kulturális eltérései megmutatkozhattak, és ezáltal a modell a nemzetközi környezetben is érvényesen megjelenhetett, az egyéni különbségekre és sokféleségre tudatosan és kellő érzékenységgel reflektált, azaz a „rendszerekre” és kontextuális hatásokra, melyek befolyásolták az eltérő kultúrában élő emberek életet (Schalock - Brown et al. 2002). Ezt az ökológiai szemléletet foglalja magában Schalock és Verdugo modellje, melyben megjelenhetnek az egyén életét meghatározó tényezők:

- „mikrorendszer: közvetlen szociális-társas berendezkedés (setting), úgymint a család, otthon, kortárs csoport, és a munkahely, ami közvetlenül hat az ember életére;

- mezorendszer: szomszédság, közösségek, a szolgáltatások és szervezetek, melyek direkt hatnak a mikrorendszer múködésére;

- makrorendszer: kulturális hatások, a kultúra átörökített mintázata, szociális-politikai faktorok, szociálpolitikai trendek, gazdasági rendszerek, közösségi-társas viszonyok (society-related factors), melyek közvetlenül hatnak az 


\section{TEMATIKUS TANULMÁNYOK - Pszi-komplexum}

egyéni értékekre, előfeltevésekre, a szavak és a fogalmak jelentésére." (Schalock - Verdugo 2002: 7)

Az életminőség rendszerszintű modellje Schalock és Vergudo szerint megváltoztathatja az egyéni gondolkodást (mind-set), és azt a szemléltet, melyet a marginalizálódott emberekről gondolnak. Mindez a mentális és viselkedési problémákkal élők ellátásában megjelenhet oly módon, hogy megújíthatja a közösségi ellátást és a rehabilitációs programok fontosságát, hangsúlyt fektet az adaptív viselkedésre, az aktív életre, életminőségre, valamint szükségletalapú és személyközpontú ellátásra is fókuszál (Schalock - Verdugo 2002). Morris és társai (2013) fókuszcsoportos kutatást végeztek egy olyan speciális csoport körében, akik mentális betegséggel (mental disorder) és enyhe értelmi fogyatékossággal (intellectual disorder) is diagnosztizáltak. Arra keresték a választ, hogy a Schalock és társai által megalkotott életminőség modell alkalmazható-e az esetükben, illetve hogy a modell mely dimenziói érvényesek ebben a csoportban. Eredményeik szerint az vizsgált dimenziók univerzálisnak mondhatóak, mind a nyolc terület spontán előkerültek a beszélgetések során. A legfontosabb terület az érzelmi jóllét, a személyközi kapcsolatok, az önmeghatározás és a szociális inklúzió kérdése volt.

Az életminőség modellnek azonban számos kritikája is megfogalmazódott. Az egyik leggyakrabban említett kritika a szubjektív és az objektív életminőségi szempontok diszkrepanciája. Hammell gerincsérüléssel élő emberek életminőség vizsgálatának eredményeképpen hívja fel a figyelmet erre, illetve ezek összehangolása miatt kvalitatív és kvantitatív kutatásmódszertani eszközök alkalmazását javasolja. Martinez-Martin és társai Parkinson kórós betegek körében végeztek kvalitatív és kvantitatív kutatást, tapasztalataik szerint a két típusú adatfelvétel más eredményeket mutat (Martinez-Martin et al. 2011). Hammell hivatkozik Bach-ra, aki már korábban is különbséget tett a megkérdezettek „tudása” és „hiedelmei” között, és felhívja az egyes típusú kutatások sajátosságára a figyelmet, miszerint a kutatók etikai relativizmussal dolgoznak, azaz, hogy a megkérdezettek állításait igaznak tekintik, illetve igaznak kell tekinteniük (Hammell 2004).

\section{I.2. AZ ÉLETMINŐSÉG DEFINÍCIÓJA}

Az egyes emberek igényei nagyban különbözhetnek, ezért nehéz meghatározni mit is jelent az életminőség. Ennek következményeként az életminőségnek számtalan definíciója létezik, és ezek tükrében a mérésére használt indikátorok is eltérőek. Noll szerint az életminőség kutatásokkal alapvetően két területet lehet mérni: a társadalmi változásokat és az egyéni és szociális jól-lét mértékét. Az életminőség kutatásoknak két pólusát jelenítik meg a skandináv és az amerikai típusú kutatások és koncepciók; előbbi az erőforrásokra és az objektív életfeltételekre, míg utóbbi az egyéni szubjektív jól-létre, mint a feltételek és folyamatok végső kimenetére helyezi 


\section{TEMATIKUS TANULMÁNYOK - Pszi-komplexum}

a hangsúlyt (Noll 2004). Az életminőség kutatásokban általában is ezek jelennek meg, azonban különböző hangsúlyokkal.

Az objektív szempontok mögött az a társadalmi és politikai konszenzus áll, hogy vannak az életben jó és rossz feltételek, mozgósítható erőforrások és a jólét szempontjából releváns dimenziók. Ezek mérhető indikátorra is lefordíthatóak úgy, mint az átlagos jövedelem, a levegő minősége, a bűnözés aránya, az oktatási rendszer, a nyugdíjkorhatár stb.

A szubjektív indikátor azt jeleníti meg, hogy az emberek hogyan érzékelik, tapasztalják az életüket, mennyire elégedettek vele (Noll 2004) (pl. barátok száma, lakókörnyezetének biztonsága, privát szféra, egészségi állapot értékelése). Ez kutatói szempontból megkérdőjelezhetetlen, azonban mint korábban Hammell megállapítására utaltam, számos vitát generált.

Az életminőség elméleti keretének és kutatási design-jának meghatározása Dr. Robert Schalock nevéhez kapcsolódik. A „The My Life: Personal Outcomes Index ${ }^{\mathrm{TM}}$ egy elméleti keretmunkán alapul, melynek célja az életminőség mérése. Az index nyolc területet tartalmaz, melyek együttesen határozzák meg a személyes jóllét egyéni érzékelését, megélését. Ez a szemlélet inkább a szubjektív jóllét mérésére fókuszál, kevésbé jelennek meg az egyén által kapott szolgáltatások, támogatások minőségi megismerése. A nyolc terület tehát: személyes fejlődés lehetősége, személyközi kapcsolatok, társadalmi befogadás, jogok, érzelmi jóllét, anyagi jóllét, testi jóllét, önmeghatározás/önrendelkezés.

Az életminőség modell egyes területeit és a hozzá kapcsolódó indikátorokat a következő táblázat szemlélteti.

1. táblázat: Az életminőség modell egyes területei és a hozzá kapcsolódó indikátorok

\begin{tabular}{|c|l|l|}
\hline Faktor & \multicolumn{1}{|c|}{ Terület } & \multicolumn{1}{c|}{ Példaszerú indikátorok } \\
\hline \multirow{4}{*}{ Önállóság } & Személyes fejlődés & $\begin{array}{l}\text { Iskolai végzettség, személyes készségek, adaptív } \\
\text { viselkedés }\end{array}$ \\
\cline { 2 - 3 } & Önrendelkezés & $\begin{array}{l}\text { Választási és döntési lehetőségek, autonómia, szemé- } \\
\text { lyes kontroll, személyes célok }\end{array}$ \\
\hline \multirow{4}{*}{$\begin{array}{l}\text { Társadalmi } \\
\text { részvétel }\end{array}$} & $\begin{array}{l}\text { Személyközi } \\
\text { kapcsolatok }\end{array}$ & $\begin{array}{l}\text { Kapcsolati háló, barátságok, társas tevékenységek, } \\
\text { interakciók, kapcsolatok }\end{array}$ \\
\cline { 2 - 3 } & $\begin{array}{l}\text { Társadalmi } \\
\text { befogadás }\end{array}$ & $\begin{array}{l}\text { Közösségi integráció/részvétel, közösségi szerepek, } \\
\text { támogatások }\end{array}$ \\
\cline { 2 - 4 } & Jogok & Emberi jogok (tisztelet, méltóság, egyenlőség) \\
\cline { 2 - 3 } Jól-lét & Eolgári jogok (jogképesség, tisztességes eljárás) \\
\cline { 2 - 3 } & Érzelmi jól-lét & $\begin{array}{l}\text { biztonság, pozitív tapasztalatok, önértékelés, stressz } \\
\text { hiánya }\end{array}$ \\
\cline { 2 - 3 } & Testi jól-lét & Egészségi állapot, táplálkozás, pihenés, szórakozás \\
\cline { 2 - 3 } & Anyagi jólét & $\begin{array}{l}\text { Pénzügyi helyzet, foglalkoztatási státusz, lakhatási } \\
\text { helyzet, anyagi javak }\end{array}$ \\
\hline
\end{tabular}

Forrás: http://www.communitylivingbc.ca/wp-content/uploads/Include-Me-Info-Sheet-Overview.pdf 


\section{TEMATIKUS TANULMÁNYOK - Pszi-komplexum}

Ebben az ábrában a példaszerű indikátorok nyújtanak segítséget egy kutatás megtervezéséhez, az egyes területek operacionalizálásához. Az életminőség kutatások jelentős része kvantitatív módszertant alkalmaz, általában egy kérdőíves felmérés, mely a vizsgált populáció speciális élethelyzetéhez, igényeihez, szokásaihoz (pl. agyvérzésen átesettek, dohányzók, fogyatékossággal élők stb.) igazítottak. Ezek a kérdőívek jellemzően a közelmúltra vonatkoznak (lásd Oregon Health Sciences University, WHO Department of mental health \& substance dependence), sok esetben a megkérdezést megelőző két hétre, így kevéssé jelenhetnek meg az adott személy életútjából fakadó erőforrások vagy hátráltató tényezők.

\section{Az akadályozottság meghatározása}

Mivel ez a hazai szakirodalomban jól dokumentált, ezért erről csak néhány megállapítást teszek.

A Funkcióképesség, fogyatékosság és egészség nemzetközi osztályozása (FNO) a megromlott egészségi állapothoz társuló funkciócsökkenés vizsgálatához nyújt útmutatót, a fogyatékosságot mintegy folyamatként tekintve. A károsodás - impairment - („A test anatómiai szerkezetét és/vagy valamely élettani funkcióját érinto problémát - beleértve a pszichés funkciókat is - összefoglaló neve) (Görög 2005), mely Kullmann Lajos szerint lehet időszakos vagy állandó, egyszerű vagy összetett és másodlagos is (Kullmann 2009).

A fogyatékosság gyűjtőfogalom, amely a testi vagy mentális károsodás következtében fellépő változások következményeit foglalja magában. A tevékenységek akadályozottságát és a részvétel korlátozottságát is magába foglalja, azaz a normális emberi léthez szükséges tevékenységek végrehajtásának akadályozottságát vagy képtelenségét jelenti (Görög 2005), és ebben az értelemben következményei nem kizárólag testre, egészségre vonatkoznak, hanem foglalkozási, jogi, társas kötelezettségek és lehetőségek korlátozódását is jelenti. A fogyatékosság osztályozható a korlátozott tevékenység szerint (mozgás-korlátozottság, látás-, hallás-fogyatékosság stb.) és az állapot tartóssága (átmeneti, tartós) és súlyossága szerint.

A hátrány (handicap) károsodásból, vagy fogyatékosságból eredő hátrány (Kováts - Tausz 1997). Magyarul a hátrányt fordítják rokkantságnak vagy akadályozottságnak is. Az akadályozottság, hasonlóan az életminőség elméletéhez, több szinten megjelenhet úgy, mint a testi funkciók és struktúrák, a tevékenységek és a részvétel (cselekvés) szintjén. Itt is megjelenik a mikro-, mezo-, makroszint, mert az akadályozottság magában foglalja az egyéni és a társas-társadalmi következményeket is, megjelenik a szociális ellátás, a foglalkoztathatóság, a lakhatási szakpolitikákban és finanszírozásban is.

Akadályozottság kérdése a jogszabályban elsődlegesen a fogyatékosság meghatározásánál jelenik meg. Magyarországon a pszichiátriai betegnek diagnosztizáltak 


\section{TEMATIKUS TANULMÁNYOK - Pszi-komplexum}

jogszabályokban nem szerepeltek külön fogyatékos kategóriaként 2013-ig, amikor pszichoszociális károsodással élő néven bekerült a törvény szövegezésébe. ${ }^{3}$

\section{Alkalmazott kutatási módszerek}

A pszichiátriai betegnek diagnosztizáltak életminőségének bemutatásához két egy kvalitatív és egy kvantitatív - adatforrást alkalmaztam.

A European Social Survey (ESS) egy standard és változó modulokból áll. A 2014es egyik változó modulban az egészséggel kapcsolatos egyenlőtlenségek (Social Inequalities in Health) kerültek a fókuszba. Ez alapján kifejezetten a pszichiátriai betegségekről és a pszichiátriai betegnek diagnosztizáltakról nem lehet megállapításokat tenni, csak általában az akadályozottsággal élőkről. Az ESS standard és változó kérdéssorában számos az életminőségre vonatkozó olyan kérdés is szerepelt, amire az életútinterjúk során az interjúalanyok nem tértek ki, ezért közlését indokoltnak tartom. Az ESS adatai alapján az életminőség faktorai közül a társadalmi részvétel (társas befogadás, tisztességes eljárás, joggyakorlás, személyközi kapcsolatok) és a jól-létet (test jól-lét) egyes elemeiről lehet megállapításokat tenni. A változó modul kérdéseire bővebben a következő fejezetben térek ki.

A kvalitatív kutatásban életútinterjúkat készítettem pszichiátriai betegnek diagnosztizáltakkal, ami áthidaló megoldást jelent az életminőség vizsgálatára és az akadályozottság-akadálymentesítés megfogalmazására is. A kvalitatív kutatásmódszertani eszközök előnye, hogy a megkérdezettek szempontjait, szubjektív tapasztalatait tárják fel, az érintetteknek lehetőségük van saját hangjukon megszólalni a kutató által. Hátránya azonban, hogy nem lehet a teljes populációra érvényes általánosításokat tenni. Ebben az esetben inkább egy etnografikus, értelmező paradigma érvényesül, mely szemben a kvantitatív módszerekkel - az életminőség vizsgálatoknál gyakran alkalmazott - mélyebb rétegekre kiterjedő elemzést biztosít.

Az interjúalanyoknak elmondtam a kutatási témát (életminőség, az életüket akadályozó és támogató tényezők), ezzel meghatározva az interjú keretét, majd azt kértem tőlük, hogy meséljék el az életüket. Az interjúk végén, amikor lehetőségem volt, egy rövid kérdőívet is kitöltettem speciálisan a pszichiátriai betegnek diagnosztizáltak akadályozottságára vonatkozóan, melyet én állítottam össze a nemzetközi szakirodalomra, a korábbi kutatásai tapasztalataimra támaszkodva, illetve konkrétan is megkérdeztem, hogy szerintük egy pszichiátriai betegnek diagnosztizált miben akadályozott, és mi jelentheti számára az támogatást. A vizsgált populáció kiterjed a pszichoszociális fogyatékkal élők önálló életvitelét támogató emberekre is. Felte-

${ }^{3}$ Ezzel a névhasználattal kapcsolatosan számos vita folyt, lásd: https://pszichoszoc.wordpress. com/2013/10/06/mi-a-pszichoszocialis-fogyatekossag/. 


\section{TEMATIKUS TANULMÁNYOK - Pszi-komplexum}

vésem szerint ők azok a személyek, akik jelentősen elősegíthetik pszichoszociális fogyatékkal élők társas integrációját.

Kutatásomban olyan pszichiátriai betegnek diagnosztizáltakat szólaltattam meg, akik nem bentlakásos vagy támogatott lakhatásban élnek és dolgoznak. Azokat tekintettem pszichiátriai betegnek diagnosztizáltaknak, akiknek van konkrét orvosi diagnózisuk és/vagy magukat pszichiátriai betegnek tartják. Az interjúban való részvétel önkéntes volt, és anonimitást ígértem az interjúalanyoknak.

Az interjúalanyok felkutatása részben hólabda mintavétellel történt, a korábbi kutatásaimból ismert személyek kapcsolathálójára támaszkodva, azonban egy ponton nem találtam több az interjúalanyt a kutatáshoz. Ennek több oka is volt: részben objektív okok, azaz a pszichiátriai betegnek diagnosztizált ismerőseim szintén érintett ismerősei nem dolgoztak, vagy nem voltak érintett ismerősei; és szubjektív okok is, a tőlem „két-három kézfogásra” lévő potenciális interjúalanyok nem szerettek volna nekem interjút adni. Néhány interjúalanyt viszont támogató személyek ajánlottak, azaz több esetben is előfordult, hogy egy támogató személy életében több pszichiátriai betegnek diagnosztizált is megjelenik. Az interjúalanyok harmadával viszont közösségi ellátást végző intézményen keresztül tudtam kapcsolatba lépni. Budapesten 30, vidéken 10 narratív életútinterjú és 28 támogatói interjú készült. A válaszadók 2/3-a nő, átlagéletkoruk 38-39 év. Az interjúk felvétele 2017-2018 között zajlott, minden esetben az interjúalanyok kérésének megfelelő helyszínen (saját lakás, kávézó, park, könyvtár, közösségi ellátást végző intézmény), az életút interjúk kb. 100-250 percet vettek igénybe, több esetben többszöri találkozás alkalmával sikerült befejezni az interjút, a támogatói interjúk jellemzően 60 percesek voltak.

\section{Akadályozottság, életminőség pszichiátriai diagnózissal}

\section{IV.1 AKADÁLYOZOTTSÁGGAL ÉLŐK ÉLETMINŐSÉGE - KVANTITATÍV ADATOK}

A pszichiátriai betegséggel diagnosztizáltak, vagy a krízishelyzeteken túljutott emberek életminőségéről általánosságban csak nagyon óvatos megállapítások tehetők. Statisztikai számbavételük számos akadályba ütközik: egyrészt a krízishelyzetek sok esetben időszakosak, a kérdezés időpillanatában nem érvényesek; másrészt ez tipikusan olyan élethelyzet vagy állapot, amiről az emberek nem szívesen nyilatkoznak, nem vállalnak fel, ezért ez rejtett betegségnek tekinthető.

Ezek az érzékenynek tekinthető szempontok már megjelennek a nagymintás európai és magyarországi adatfelvételekben is. A hazai népszámlálásokkor a korábbi „Milyen fogyatékossága van Önnek?” kérdést a 2016-os Mikrocenzusban felváltotta a „Vannak-e nehézségei az emlékezéssel/ önellátással stb. kapcsolatosan?” típusú kérdések. 


\section{TEMATIKUS TANULMÁNYOK - Pszi-komplexum}

A pszichiátriai betegségek tekintetében a European Social Survey (ESS) standard, minden alkalommal lekérdezésre kerülő kérdése „Akadályozza-e Önt mindennapi tevékenységében bármilyen módon valamilyen tartós betegség, rokkantság, rossz egészségi állapot vagy mentális probléma? Ha igen, akkor milyen mértékben?", illetve a korábban ismertetett, tágabb értelemben vett életminőséggel kapcsolatos kérdések is megjelennek, mint például „Mindent egybevetve, mennyire érzi magát boldognak?” (ESS 2012). Az ESS változó moduljában rendszeresen előfordulnak olyan témák, ahol a fogyatékosság vagy a mentális egészség (egészségügyi, munkavállalási, szubjektív jól-lét tematikák) kerültek fókuszba.

\section{IV.2 AKADÁLYOZOTTSÁG ÉS EGÉSZSÉGÜGY AZ EUROPEAN SOCIAL SURVEY ${ }^{4}$ ALAPJÁN}

A 2014/2015-ös ESS7 felmérésben a változó modul a „Social Inequalities in Health”, melyben az előbb ismertetett kérdés, továbbá a gyümölcs-, alkohol-, cigarettafogyasztás, egészségügyi ellátások elérhetősége, sportolási szokások szerepelnek. Ebben a kérdésblokkban nem szerepeltek fogyatékossági típusok, ezért a következőkben a standard blokkban szereplő „akadályozottság” kérdést felhasználva ismertetem az egészséggel kapcsolatos eredményeket. Mivel az egészség alkérdőív igen tág témákat foglal magában, ezért tanulmányomban nem kerül ismertetésre az ESS egészségügyi blokkjában szereplő összes kérdés, csak az életminőségre és a különböző kezelésekre vonatkozóak.

Az ESS7 felmérésben Magyarországon összes 1698 fó válaszolt a kérdésekre, ebből 499 fő $(29,4 \%)$ érezte úgy, hogy egészsége miatt kisebb vagy jelentősebb mértékben akadályozott a mindennapjaiban. (Az akadályozottság és a fogyatékosság különbségére hívnám fel itt a figyelmet. Az ESS akadályozottság mutatója jóval kevésbé medikális, inkább a hétköznapi megküzdési stratégiákat tükrözi, míg a 2011-es Népszámlálás, ami az egészségi állapotot méri fel. Itt ugyanis az önbevalláson alapuló válaszadók szerint a lakosság mindössze 4,6\%-a vallja magát fogyatékossággal élőnek (KSH 2013).) A korábbi statisztikai adatoknak megfelelően az akadályozottak 2/3-a (305 fó) volt nő, és csak 1/3-a (194 fő) volt férfi, átlag életkoruk 63 év volt. Az akadályozottsággal élők 35,47\%-a faluban vagy községben, 32,87\%-a városban vagy kisvárosban lakott, 31,06\%-a pedig nagyvárosban (ebből 3,4\% az agglomerációban) élt, illetve $0,6 \%$ tanyasi környezetben. Jellemzően aluliskolázottak voltak, 35,9\%-uknak legfeljebb a befejezett 8 általános iskolai végzettsége volt (178 fó), szakmunkás bizonyítvánnyal 32,5\% rendelkezett (161 fő), érettségivel 18,7\% (93 fő), míg valamilyen felsőfokú végzettséggel 12,7\%-uk (63 fő). Munkaerőpiaci stá-

${ }^{4}$ Az ESS adatai, kérdőív letölthető az http://www.europeansocialsurvey.org/ vagy a http://ess.tk.mta.hu/ess/ oldalakról. Az itt bemutatott adatok az ESS módszertani javaslata alapján súlyozva kerülnek bemutatásra. 


\section{TEMATIKUS TANULMÁNYOK - Pszi-komplexum}

tuszukat tekintve a kérdezéstől számított egy hétre vonatkozó információkat kértek a válaszadóktól (ezek egymást nem kizáró válaszlehetőségek, ezért a százalékok öszszege meghaladja a 100\%-ot). Ez alapján az akadályozottsággal élők 22,8\% (114 fő) dolgozott, 2,2\% tanult (11 fö), munkanélküli volt 6,2\% (26 fő), tartós betegség vagy fogyatékosság miatt támogatásban részesült 17\% (85 fő), nyugdíjas 62,3\% (311 fô) volt, háztartásbeli vagy anyasági támogatást kapott 22,6\% (113 fő). ${ }^{5}$

\section{Társadalmi részvétel}

Az ESS kérdőívében a társadalmi-politikai-közéleti aktivitásra vonatkozó állandó kérdések az életminőség modell társadalmi részvételének a társadalmi befogadás, joggyakorlás dimenzióinak volt megfeleltethető, valamint az önállóság-önrendelkezés területét fedte le. A kérdések esetében a válaszadók 0-tól (egyáltalán nem) 10-ig (teljes mértékben) terjedő skálán értékelhették a politikai rendszer egyes elemeit, vagy saját cselekvőképességüket.

2. táblázat: Politikai attitűd (egyáltalán nem válaszok \%-os aránya)

\begin{tabular}{|l|c|c|}
\hline & Akadályozottak & $\begin{array}{c}\text { Nem } \\
\text { akadályozottak }\end{array}$ \\
\hline $\begin{array}{l}\text { Véleménye szerint Magyarországon a politikai } \\
\text { rendszer mennyire teszi lehetővé, hogy az Önhöz } \\
\text { hasonló emberek beleszóljanak abba, hogy a kor- } \\
\text { mány mit csinál? }\end{array}$ & 36,2 & 31,4 \\
\hline $\begin{array}{l}\text { Ön szerint Magyarországon a politikai rendszer } \\
\text { milyen mértékben teszi lehetővé, hogy az Önhöz } \\
\text { hasonló emberek befolyásolják a politikát? }\end{array}$ & 39,1 & 32,0 \\
\hline $\begin{array}{l}\text { Mennyire bízik abban, hogy a saját képességei lehe- } \\
\text { tővé teszik, hogy részt vegyen a politikában? }\end{array}$ & 44,4 & 28,2 \\
\hline $\begin{array}{l}\text { Személyesen mennyire érzi úgy, hogy könnyű dolog } \\
\text { részt venni a politikában? }\end{array}$ & 38,05 & 27,9 \\
\hline
\end{tabular}

Forrás: saját számítás az ESS adatai alapján

1-2. kérdés esetében a Pearson-féle Chi-négyzet szerint az összefüggés nem szignifikáns, a 3-4. kérdés esetében a Chi-négyzet 0,005 alatti értéket vett fel.

${ }^{5}$ A megkérdezettek azon része, mely nem jelölte, hogy akadályozottsággal él, átlagosan 44 évesek voltak, 44\%-uk férfi, 56\%-uk nő. 64,5\%-a dolgozott, 10,3\%-a tanult, 4\%-a munkanélküli volt, 0,4\% (5fó) kapott fogyatékossággal kapcsolatos támogatást, 19\%-a nyugdíjas, 20\%-a háztartásbeli, anyasági vagy támogatást kapott, 3,5\%-uk valamilyen más tevékenységet végzett. 15\% legfeljebb általános iskolai, 28\%-uk szakmunkásképző, 36\%-a érettségivel, 21\%-uk felsőfokú végzettséggel rendelkezett. Nagyvárosban és annak agglomerációjában 28\%, városban-kisvárosban 39\%, faluban vagy tanyasi területen 33\%-uk lakott. 


\section{TEMATIKUS TANULMÁNYOK - Pszi-komplexum}

Mind az akadályozottsággal élők, mind azok, akik nem élnek akadályozottsággal kb. harmada érezte úgy, hogy a politikai rendszer egyáltalán nem teszi lehetővé, hogy beleszóljanak, vagy befolyásolják azt. A saját érdekérvényesítő képességbe vetett bizalom viszont az akadályozottsággal élők körében jóval kisebb mértékű volt, a válaszadók közel fele egyáltalán nem érezte azt, hogy képességei engednék, hogy a politikai életben részt vegyen, míg azok, akik nem érezték magukat akadályozottnak csak valamivel több, mint a negyedük gondolkodott ehhez hasonlóan.

A tényleges közéleti-politikai cselekvésekre vonatkozóan eldöntendő kérdések szerepeltek a kérdőívben.

3. táblázat: Politikai-közéleti aktivitás (igen válaszok \%-os aránya)

\begin{tabular}{|l|c|c|}
\hline & Akadályozottak & $\begin{array}{c}\text { Nem } \\
\text { akadályozottak }\end{array}$ \\
\hline $\begin{array}{l}\text { Kapcsolatba lépett politikussal, kormányzati, } \\
\text { vagy önkormányzati képviselővel? }\end{array}$ & 10,1 & 8,5 \\
\hline $\begin{array}{l}\text { Az elmúlt 12 hónap során előfordult, } \\
\text { hogy Ön tiltakozó levelet, nyilatkozatot írt alá? }\end{array}$ & 2,6 & 6,3 \\
\hline $\begin{array}{l}\text { Részt vett más szervezet vagy egyesület } \\
\text { munkájában? }\end{array}$ & 3,2 & 3,3 \\
\hline Részt vett törvényes, nyilvános felvonuláson? & 2,2 & 3,9 \\
\hline
\end{tabular}

Forrás: saját számítás az ESS adatai alapján

Ebben az esetben a Pearson-féle Chi négyzet együttható csak a 2. kérdés esetében mutat szignifikáns összefüggést

A politikusokkal, kormányzati-önkormányzati képviselőkkel való kapcsolatba lépés az akadályozottsággal élők körében volt gyakoribb, feltehetően ez a különböző támogatások igénylésével magyarázható. A másik vizsgált véleménynyilvánítási terület mindegyikében a nem akadályozott válaszadók voltak aktívabbak, de a nem politikai szervezetben, vagy egyesületben közel azonos - bár nagyon alacsony - arányban vett részt mindkét csoport. Az eltérések egy kérdés kivételével nem szignifikánsak, ami arra utal, hogy általában Magyarországon az akadályozottság mértékétől függetlenül alacsony a politikai aktivitás.

\section{Általános jól-lét}

Az általános jólléttel kapcsolatos kérdéseket (Mindent egybevetve, mennyire érzi magát boldognak?; Mindent összevetve mennyire elégedett mostani életével?) hasonlóan 0-10-es skálán értékelhették a válaszadók. 


\section{TEMATIKUS TANULMÁNYOK - Pszi-komplexum}

A szubjektív egészségi állapotukat az akadályozottsággal élők 11,4\%, míg akik nem élnek akadályozottsággal 76,3\% ítélte meg jónak, vagy nagyon jónak (Pearson-féle Chi-négyzet $=0,000$ ). Baráti, családi, kollegiális viszony tekintetében az akadályozottsággal élők 20\%-ára volt jellemző, hogy soha nem és csak 7,8\%-uk találkozik emberekkel legalább hetente egyszer. A többi válaszadó 4,6\%-a soha nem találkozik emberekkel, és akik hetente legalább egyszer találkoztak, azok aránya 16,1\%. A személyes jó barátnak tekintett emberek száma a két csoport esetében átlagosan 2 barátot jelentett, de az akadályozottsággal élők 10\%-ának, míg a többi válaszadó 5\%-ának nem volt személyes jó barátja, és 10 vagy annál több barátja az akadályozottsággal élők 5\%-ának, míg a magukat nem akadályozottsággal élőnek meghatározók 16\%-ának volt (Pearson-féle Chi-négyzet=0,000).

Társadalmi részvétel, személyközi kapcsolatok témája az ESS kérdőívben a családtag, barát, szomszéd vagy bárki más gondozására vagy megsegítésre vonatkozó kérdés által is megragadható. A megkérdezett akadályozottsággal élők 9,1\%-a, míg akik nem jelölték meg, hogy akadályozottak 8,2\%-a tölt időt mások gondozásával, segítésével. Ez az összefüggés nem szignifikáns (Pearson-féle Chi négyzet=0,56), tehát nincs jelentős különbség a két csoport tekintetében, ami arra enged következtetni, hogy azok, akik akadályozottnak érzik magukat hasonló arányban képesek törődni másokkal, mint azok, akik nem érzik magukat akadályozottnak.

A szubjektív jólléttel kapcsolatosan hangulati, a mindennapi életet befolyásoló tényezőkre kérdeztek rá. (Ebben az esetben Soha vagy szinte soha, Néha, Többnyire, Mindig vagy majdnem mindig, Nem tudom válaszok közül lehetett választani.)

4. táblázat: Szubjektív jól-lét

\begin{tabular}{|l|c|c|}
\hline $\begin{array}{l}\text { Az elmúlt egy hétben soha vagy szin- } \\
\text { te soha nem érezte.... }\end{array}$ & $\begin{array}{c}\text { Akadályozottsággal } \\
\text { élők (\%) }\end{array}$ & $\begin{array}{c}\text { Akadályozottság nélkül } \\
\text { élők (\%) }\end{array}$ \\
\hline magát levertnek? & 11,2 & 47,1 \\
\hline $\begin{array}{l}\text { azt, hogy mindenhez nagy erőfeszí- } \\
\text { tésre volt szüksége? }\end{array}$ & 15,2 & 53,8 \\
\hline $\begin{array}{l}\text { hogy fáradt, nem tudja magát } \\
\text { kipihenni }\end{array}$ & 9,1 & 27,1 \\
\hline volt boldog? & 11,7 & 5,2 \\
\hline magányosnak magát? & 45,5 & 70 \\
\hline élvezte az életet? & 20,2 & 5 \\
\hline volt szomorú? & 19,6 & 53,6 \\
\hline $\begin{array}{l}\text { érezte azt, hogy elfásult, nincs kedve } \\
\text { semmihez? }\end{array}$ & 22,6 & 54,1 \\
\hline
\end{tabular}

Forrás: saját számítás az ESS adatai alapján

A Pearson-féle Chi négyzet együttható minden esetben szignifikáns összefüggést mutat, értéke 0,005 alatti. 


\section{TEMATIKUS TANULMÁNYOK - Pszi-komplexum}

Általában megállapítható, hogy az akadályozottsággal élők szubjektív jóllétének megítélése jóval negatívabb volt, mint azoké, akik nem érzik úgy, hogy akadályozottsággal élnének. Kivétel nélkül minden pozitív attitűd, életminőségi mutató kedvezőbb és minden negatív attitűd mutatója kedvezőtlenebb volt az akadályozottsággal élők körében.

\section{Az egészségügyi ellátásához való hozzáférés}

Az életminőség faktorok közül a jól-lét, azon belül is a testi jól-létre lehet következtetni az egészségügyi ellátás igénybevételének gyakoriságáról. Az akadályozottsággal élők 87,8\%-a fordult háziorvoshoz és 62,2\%-uk szakorvoshoz a vizsgálat idejéhez viszonyított elmúlt 12 hónapban. 11,5\%-uk mondta azt, hogy valamilyen okból kifolyólag nem volt számára elérhető az orvosi ellátás. A leggyakrabban említett okok a következők: 2\% (10 fó) nem tudta kifizetni, 3\% (15 fó) esetében a szükséges kezelés nem volt elérhető lakóhelye közelében, 6,8\% (34 fö) túl hosszú volt a várólista, 4,4\% esetében nem volt időpont ( 22 fó). Akik nem élnek akadályozottsággal kevesebbet járnak orvoshoz, mindössze 56\%-uk járt háziorvosnál és 20\%-uk valamilyen szakorvosnál, és 3,7\%-uk állította, hogy valamilyen okból kifolyólag nem volt elérhető az ellátás (a vizsgált két csoport közötti eltérés mindhárom kérdése esetén, nem meglepő módon, szignifikáns, Pearson-féle Chi-négyzet=0,000). Utóbbi kérdésnél és vizsgált csoportnál annyira kevés a válaszadók elemszáma, hogy az eredményeket nem érdemes közölni.

Az alternatív gyógymódok közül a legnépszerúbb az akadályozottsággal élők körében a fizioterápia (17,6\%, 86 fő), a gyógynövényes kezelés, masszázsterápia (7,6\%-7,6\%, 38 fó), a homeopátia (3,8\%, 19 fó) és az oszteopátia/csontkovácsolás (2,4\%, 12 fó). Ezzel szemben szinte alig valaki járt akupresszúrára, kínai gyógyászhoz, kiropraktorhoz, hipnoterápiára, reflexológiára vagy spirituális gyógyászhoz. Azok körében, akik nem akadályozottak a hétköznapokban a gyógynövényes kezelés és a masszázsterápia (4,1-4,1\%, 49 fó), fizioterápia (2,9\%, 35 fó) és homeopátia (2,6\%, 35 fö) alkalmazása volt a leggyakoribb. Az egyes gyógymódok használatának bemutatása inkább illusztratív jellegű, mivel szignifikáns eltérés a magukat akadályozottnak és a magukat akadályozottnak nem vallók között csak a fizioterápiás kezelés igénybevételének esetében volt.

Összességében az ESS adatok alapján megállapítható, hogy azok az emberek, akik magukat egészségi állapotuk miatt akadályozottnak érzik, és akik egészségi állapotuk miatt magukat nem érzik akadályozottnak az életminőségre vonatkozó kérdésekre adott válaszaiban eltérések mutatkoznak. A társadalmi részvétel faktorban a magukat akadályozottnak érzők politikai-közéleti érdekérvényesítő képességüket alacsonyabbnak ítélték meg, társas kapcsolataik szegényesebbek, mint akik nem ítélték magukat akadályozottnak. Mindemellett a politikára gyakorolt egyéni 


\section{TEMATIKUS TANULMÁNYOK - Pszi-komplexum}

hatásuk megítélése, a politikai-közéleti aktivitás (szervezetekben, egyesületekben való részvétel, petíció aláírása) szintje mindkét csoportban nagyjából azonos. Ez az eredmény nem az akadályozottság mértékével van összefüggésben, hanem sokkal inkább egy általános apolitikus attitűdöt feltételez.

Az általános jól-lét faktorban a szubjektív jól-létet (boldogság, magányosság, szomorúság, elhagyatottság érzése) és a testi jól-létet leíró mutatók mentén is találhatók különbségek a vizsgált csoportok között. A testi jól-lét megítélése nem meglepő, hiszen a csoportképző változónak az egészségi akadályozottság szubjektív megítélését alkalmaztam. A szubjektív jól-lét mutatóiban tapasztalható eltérés arra enged következtetni, hogy akik magukat egészségi állapotuk miatt akadályozottnak érzik, azok az emberek az érzelmi jól-lét és társas kapcsolat szempontjából is hiányosságokat élnek meg, boldogtalanabbak, magányosabbak, mint akik egészségi állapotuk miatt nem érzik magukat akadályozottnak. A két vizsgált csoport egyetlen mutatóban, a másoknak való segítségnyújtásban, mutatott hasonló értéket, amely attitűd mögött azonban több motiváló tényező is lehet, például a későbbi reciprok segítségnyújtás, vagy az önigazolás (Vályi 2008).

\section{IV.3. PSZICHIÁTRIAI BETEGNEK DIAGNOSZTIZÁLTAK ÉLETMINŐSÉGE KÉT ÉLETÚT ALAPJÁN - KVALITATÍV ADATOK}

Az életminőség kérdőívek módszertana szerint a kérdések többnyire a közelmúltra - egy-két hét, esetleg pár hónap - vonatkoznak, azonban a közelmúlt eseményei jobban megérthetőek, ha ismerhetőek az előzmények. Esetemben van lehetőség egy tágabb kontextusban elhelyezni az élettörténetek jelenlegi, pillanatnyi helyzetét, illetve rávilágítani az azokban rejlő tartós erőforrásokra.

Jelen tanulmányban két életút segítségével mutatom be pszichiátriai betegnek diagnosztizáltak életminőségét. Nem mélyülök el az életutak narratív elemzésébe, és nem szorítkozom az életutak utolsó pár hónapjának ismertetésére, hanem az életminőség faktorok egyes dimenzióinak érvényesülését, vagy hiányosságait mutatom be. Az egészségügyi ellátást minden esetben kissé részletesebben tárgyalom, arra a kérdésre keresve a választ, hogy mennyiben járul vagy járult hozzá az érintettek felépüléséhez, szubjektív jóllétéhez, életminőségük javításához.

Egy férfi és egy nő interjúalany életén keresztül mutatom be a pszichiátriai betegnek diagnosztizáltak életminőségét, bár interjúalanyaim - akárcsak az ESS adatokban is - 2/3-a nő volt. A hólabda mintavétel hátrányai miatt interjúalanyaim homogenitást mutattak az iskolai végzettség szempontjából, 2/3-uk ugyanis felsőfokú végzettséggel rendelkezik. A most bemutatott interjúalanyok közül az egyiknek van diplomája, a másiknak a szakközépiskolai érettségi a legmagasabb iskolai végzettsége. Egyikük Budapesten él, míg a másik az interjú előtt egy évvel elköltözött Magyarországról, de mindketten budapesti születésűek. Interjúalanyaimat álnéven 


\section{TEMATIKUS TANULMÁNYOK - Pszi-komplexum}

említem, és az idézeteket azokon a helyeken módosítom, melyek sérthetik az anonimitást.

Választásom elsősorban azért erre a két interjúalanyra esett, mert „kívülről” nézve kiegyensúlyozott életet élnek: önálló családot alapítottak, anyagi jól-lét jellemzi őket, lakhatási körülményeik biztosak, jól fizető munkájuk van, ahol több emberért felelősek, kialakult baráti kapcsolataik vannak. Azonban, ha elmesélik életüket, kiderül, hogy volt olyan szakasz, amikor pszichés és fiziológiai állapotuk alapján az orvosok nem bíztak felépülésükben. Továbbá nyilvánvalóvá válik, hogy a kiegyensúlyozottság látszata mögött (az interjúk elkészítésekor is) komoly erőfeszítések húzódnak, pszichés állapotuk megfelelő szinten tartása végett mindketten házastársaikkal közösen kialakított életvezetési stratégiát folytatnak és gyógyszert szednek.

Az életminőség illusztrálásához vezérfonalként a korábban ismertetett modellt alkalmazom.

\section{1. faktor: önállóság}

Önállóság az életmód modellben a személyes fejlődés területének indikátorai az iskolai végezettség, személyes készségek stb. Az általam vizsgált populáció esetében kiemelten fontos a pszichiátriai betegségek első tüneteinek megjelenése, az erre való személyes és családi reakció, a kezelések, intézményes karrier kezdete, mert ez erőteljesen befolyásolja az iskolai részvételt és a személyes készségeket is, úgymint az önbizalom vagy a motiváltság.

\section{1. eset}

Zoltán 49 éves, Budapesten él édesanyjával, párjával és nevelt fiával. Életében a pszichiátriai betegség tünetei és a szenvedélybetegség csak fiatal felnőtt korában jelentkeztek. Gyerekkorának egyik meghatározó élménye az elfogadás, elismerés, szeretet.

\footnotetext{
„Úgynevezett jó tanuló jó sportolónak soroltak annak idején, ez volt hoszszú-hosszú ideig, amit fontosnak tartok, mert így az idő múlásával úgy gondolom, annak az emberkének majd kezd cseperedni, serdülni igen is kellenek azok az impulzusok, amit meg kell kapnia, és én megkaptam a tanáraimtól, a családomtól és volt benne fegyelem, tisztelet, szeretet, volt benne elismerés gondoskodás." (49 éves férfi)
}

Személyes képességeinek, tehetségének felismerése első munkahelyének köszönhető, ez mai napig meghatározza életét: 


\section{TEMATIKUS TANULMÁNYOK - Pszi-komplexum}

„Ezt 4 év alatt sikerült belölünk kiverni, mondhatom, hogy mint pályaelhagyóként érettségiztünk le. Mondhatom, hogy nagyon nagy szerencsémre, mikor elkezdtem dolgozni a belvárosban egy kereskedésben, ahol nagyon jó társaságba kerültem és nagyon megtetszett ez a kereskedelmi élet, adni-venni." (49 éves férfi)

Zoltán ekkor felismerte önmagában azokat a képességeket, ami egy jó és sikeres kereskedő képességei, és ezt kamatoztatta.

„Neki volt pénze, nekem volt tapasztalatom és visszakerültem a vendéglátóba, és nagyon hamar visszakerültem abba az életbe, amiből kiestem. Két választási lehetősége van egy kocsmárosnak vagy éttermesnek, vagy konzekvensen nem partnere senkinek, vagy konzumál mindenkivel [...] de engem sem kellett félteni, azt ugye mondtam, mindig is szerettem elmenni, jókat inni, jól érezni magamat, sorolhatnám itt az összes italféleséget mind szerettem, nem azért, hogy kiüssem magam, de szerettem, megszoktam." (49 éves férfi)

Zoltán életében alapvetően meghatározó önrendelkezés, a választási és döntési lehetőség, a személyes kontroll az alkohol és a drogfüggőség kezelését jelenti. Az üzleti életben nagyon sikeres volt, azonban az alkohol és a drogok hatására pszichiátriai betegség tüneteit jelentkeztek: üldözési mánia és hallucináció. Felesége elhagyta, ekkor 38 éves volt. Családja támogatásával felkeresett 8-10 pszichiátert, majd a korábbi OPNI-ban egy rezidens doktornő segítségével tudta elhagyni az italt és a drogokat.

„Arányaiban úgy állította föl, hogy 95 százaléka én vagyok, a gyógyszerek támogassanak 2-3 százalék 1-2 százalékban ő (doktornő - a szerk.). Ez egy kicsit furcsának hangzott, de elfogadtam. [...] Ez azóta a kezelés óta nem ittam semmit sem, tiszta vagyok. Se a drogokkal, sem az alkohollal kapcsolatban vagy a droggal nem éreztem azt, hogy tördelnem kell a kezemet, meneküljek, hogy nem tudom megállni." (49 éves férfi)

\section{2. eset}

Diana 37 éves, férjezett, háromgyerekes nő. Budapesten született és élt, 35 éves korában költözött el Magyarországról. Élete első 4,5 évében nagyszüleivel élt, majd miután szülei önálló lakáshoz jutottak, magukhoz vették, és ettől kezdve megváltozott az élete. Gyermekkorának meghatározó élménye édesanyja ellene irányuló verbális és fizikai agressziója, az elutasítás, kritizálás, kontrollálás, mely áthatotta az életét és az egész családjuk életét. 


\section{TEMATIKUS TANULMÁNYOK - Pszi-komplexum}

„Nagyon biztató közeg (nagyszülők - a szerk.), tanuló, biztató bármit elérhetsz az életbe. Ez nekem egy nagy trauma volt mikor onnan kikerültem és bekerültem az otthoni az elég távol tartó, ridegnevelési közegbe. Olyan családból származom vagy éltem, ahol az anya hordta a nadrágot, rendkívül nagy elvárásokkal, szigorú erkölcsökkel legalább is ezt kommunikálta kifelé, ez ilyen bántalmazó nevelési elv is volt, nálunk rendszeres volt a fizikai büntetés alkalmazása." (37 éves nő)

Diana nyilvánvaló mentális problémai 16 éves korában kezdődtek, ugyan le tudott érettségizni, de a felsőoktatási felvételijei sorozatos kudarcot vallottak, ezért egy két éves technikumi végzettséget szerzett. 19 éves korában már súlyos evési zavarai is voltak, a családjából egy házasságba menekült, ami fél év után válással végződött, amit újabb kudarcnak ítélt meg, és állapota még inkább romlott. Története szerint életében ez az időszak jelentette a legmélyebb krízist, 21 és 23 éves kor között több öngyilkossági kísérletet is elkövetett.

„Folyamatosan öngyilkossági kísérleteim voltak, evészavarom volt, depresszió meg minden, ami szóba jöhetett. Nyilvánvalóan bekerültem az egészségügyi ellátó rendszerbe, itt jött a következő érdekes dolog, hogy az anyám nem volt hajlandó elfogadni saját felelösségét ebben a helyzetben. Mert ugye az evészavarokat klasszikus szinten családterápiával kell kezelni." (37 éves nő)

Dianát ebből az állapotból az mentette meg saját narratívája szerint, hogy megismerkedett jelenlegi férjével.

„Soha nem billent volna úgy helyre az önértékelésem, hogy lássam, hogy képes vagyok olyan dolgokat elérni, hogy okos vagyok, tehetséges vagyok, hogy nem én vagyok utolsó a sorban, hogy erre is képes vagyok, hogy lehet engem szeretni, ezt én mind-mind a férjemnek köszönhetem. Úgy, hogy bekerültem az egészségügyi ellátó rendszerbe, bekerültem a pszichiátriára, de igazából semmit nem tett hozzá. Nem mondom, hogy rosszabb helyzetbe kerültem, de egy hajszállal nem kerültem jobb helyzetbe az évekig tartó kezelés semmi eredményre nem vezetett. Többször próbálkoztam utána pszichiáterhez járni, mert ugye azért voltak depressziós időszakaim, de végül a férjem segített." (37 éves nő)

Diana személyes önrendelkezése, autonómiája, kontrollja tulajdonképpen a férjével való szimbiózist jelenti. A férje biztatására végezte el a főiskolát, váltott munkahelyet és jelenleg egy multinacionális vállalatnál középvezetői pozícióban dolgozik külföldön, majdnem 100 beosztottal. Szinte minden döntést, változtatást, választást közösen hoztak, Diana férje mintegy szupervizor és coach is müködik. 


\section{TEMATIKUS TANULMÁNYOK - Pszi-komplexum}

„Mindent rábízhatok, mindenben partner, nincs olyan, amit nem mondhatok el neki, képes a saját problémáját elnyomni azért, hogy az enyémmel tudjon foglalkozni, ugyanakkor képes arra, hogy egészségesen kritizáljon, ez nem megy át egy istenítésbe, meg tudja mondani, ha hülye vagyok, meg tudja mondani, ha valami rossz döntés volt [...] és onnan átkerültem a gyógyszer céghez és onnan elég meredeken megy fölfele a karrierem. Kezdtem gyakorlatilag egy szakmunkásként és most már elég magasra eljutottam. De mondjuk ez a férjem folyamatos biztatása, hogy kirugdosta belölem a föiskolát, de olyan szinten, hogy szokás szerint mondtam, hogy nem tudom megcsinálni, nem éri meg, ő összevakart, ott ült mellettem és volt olyan, hogy gépelt helyettem és addig rugdosta a szakdolgozatot, amíg készen nem lett. Ő ilyen szinten rakott össze elemenként. Ő támogatta, hogy akarjak többet, menjek külföldre, képes vagyok rá, meg tudom csinálni. Általában az szokott lenni, hogy ő kitalálja, hogy mi legyen, javaslatokat tesz, hogy szerinte ez jó ötlet lenne és nekem már csak meg kell valósítani." (37 éves nő)

Diana állapota stabilizálódott férje mellett, ám amikor nevelő nagyszülei meghaltak, újra pszichiátriai gyógyszert kellett szednie. Azonban az étkezési problémai nem múltak el teljesen.

Az önállóság faktor esetében a személyes fejlődés területén két eltérő életutat látunk, egy támogató és egy kifejezetten bántalmazó közeget. Az önrendelkezés területén mindkét interjúalany esetében a legmeghatározóbb a személyes kontroll. Míg Diana úgy érezte totális elnyomásban él, egyetlen területe van az életének, ami felett ő rendelkezik és ez a teste, ezért nagyon erős kontroll gyakorolt felette, addig Zoltán a pénztől, a gazdasági és társas sikerei következtében kontrollvesztetté vált és politoxikomán lett. Mindketten pszichiátriára kerültek, Zoltánnak szerencsére sikerült megfelelő kezelőorvost találnia, Diana viszont egy elfogadó, segítő szerelmi kapcsolat hatására tudott állapotán változtatni. Az interjú készítésekor az önállóság tekintetében életükre elégedetten tekintenek, azonban ők maguk is megfogalmazzák, hogy újabb állapotromlás bekövetkezhet életükben, korábbi tüneteik (gyógyszerfüggőség, evési zavarok) visszatérhetnek.

\section{2. faktor: társadalmi részvétel}

\section{1. eset}

Zoltán bár Budapesten él, mégis egy kisvárosinak mondható közösség veszi körül. Sok embert ismer a korábbi iskoláiból, sport és a munkahelyei révén, tágabb családjának több tagja is itt él, akikkel aktívan tartja a kapcsolatot, mindig csörög a telefonja Természetesen ehhez hozzájárul Zoltán személyisége is: 


\section{TEMATIKUS TANULMÁNYOK - Pszi-komplexum}

„Ezt mondom mindig a nevelt fiamnak is, hogy olvass rengeteget, meg kell tanulnod, hogy ki tudd fejezni magad, hogy el tudd mondani a gondolataidat, hogy irányítani tudj egy beszélgetést, hogy meggyőző tudjál lenni stb.stb. Az, hogy bíznak bennem most is, akik körülöttem vannak, egyrészt bizonyítottam, nap, mint nap bizonyítok, tehát nagyon nehéz helyzeteket tudok megoldani, mert olyan emberi kapcsolataim alakultak ki, hogy van kitól segítséget kérnem." (49 éves férfi)

Zoltán a saját mikroközösségében aktív és népszerű, kiterjedt üzleti és emberi kapcsolatai vannak, párkapcsolatban él, és körülveszik olyan barátok, akikkel bizalmas dolgait is megoszthatja.

A munkavállalás a társadalmi részvétel egyik formája, mind közösségi, mind pénzügyi (egyéni és össztársadalmi), mind az egyén életmódját, napjainak strukturáltságát tekintve. Zoltán általában vállalkozóként dolgozik, ami az interjú készítésekor jelentős stresszforrás volt számára.

„A Xanaxot már szedem 13 éve. Az orvos felírja én meg szedem. Igazán már rám van bízva ambulánsan, voltak jobb idók, amikor nem kellett annyi, de a sok munkából adódon, a stressz, sok feszültség meg egyéb más miatti szorongások miatt az utóbbi 1-2 évben egy kicsit meglódult." (49 éves férfi)

Életének legsúlyosabb krízisében 1 évig volt betegszabadságon, ezért elindították a megváltozott munkaképességűvé nyilvánítási eljárást, akkor még leszázalékolták, és azóta is ebben a státusban van, megfelelő időközönként jár a felülvizsgálatokra.

„A legutolsó most decemberben volt és mondám, hogy igen konkrét elképzelésem van, növénytermesztéssel és állatokkal szeretnék foglalkozni. Vidéken, van is ott egy barátom, aki ezt csinálja, mert nekem elegem van ebből az egészböl. Ha egy ilyen jellegü iskolába el tudnának küldeni szívesen, elvégezném. Nagyon jó ötlet. De nincs ilyen iskola. Nem mondanak semmit, csak küldik a papírt, nem úgy van, hogy annyira akarják, hogy a munka világába visszamenjen." (49 éves férfi)

\section{2. eset}

Diana állítása szerint kevés, ám mély kapcsolattal rendelkezik. Számára a mai napig meghatározó édesanyja elutasító magatartása, és a férje támogató kapcsolata, ezen kívül van egy pár barátnője és az egyik testvérére mindig számíthat.

„Egyszerüen olyan elmebetegként áll a dolgokhoz, hogy átmegy sértegetésbe, piszkálásba, minősit, bánt, nem lehet erről egyszerüen beszélni vele, és le is írom neki, hogy anyu nem fogok addig veled beszélni, amíg nem fogod fel, hogy 


\section{TEMATIKUS TANULMÁNYOK - Pszi-komplexum}

nem vagyok öt éves és nem beszélhetsz így velem. Egy három gyerekes 37 éves fél világot igazgató nővel, nem beszélhetsz így. Ha ott lennék, egyébként meg is ütne, simán kinézem belőle." (37 éves nő)

Emellett Dianának nagyon kiterjedt ismerősi köre van, blogot írt, rengeteget chatelt, és a gyerekeik és a kutyáik révén is több hálózatnak tagja, aktív Facebook tag.

„Látom, hogy mi van velük, nagy részük átevődött a Facebookra (a blogolásból - a szerk.). Nincsen szükségem a külső megerősítésre, hogy valamit jól csinálok, vagy jó fej vagyok, mint ahogy régebben volt." (37 éves nő)

Diana életét jelentősen befolyásolja a munkahelyi emberi viszonyok kezelése, különösképpen, azóta amióta menedzseri pozícióba került. Azonban elmondása szerint ez számára rengeteg kihívással jár, elsősorban az asszertív és hatékony kommunikációt, valamint saját indulatainak kezelését kell megtanulnia.

„Menedzserként tudok építő kritikát visszafolyatni az embereim felé. A mai napig problémát okoz, hogy ne negatív tippeket adjak. Annyira mélyen begyökerezett, rossz élményem van ezzel kapcsolatban, hogy ez nap, mint nap elöforduló konfliktus." (37 éves nő)

A társadalmi részvétel faktor tekintetében meghatározó, hogy mindkét interjúalany alapvetően extrovertált személyiség, ezért társas kapcsolatokkal rendelkeztek korábban is, és az interjú készítésekor is. Jogok tekintetében a feléjük tanúsított nem kellő tiszteletről, méltóságról az egészségügyi és a szociálpolitikai ellátás kapcsán beszéltek. Mindkettőjük egészségi és mentális állapotát jelentősen befolyásolta munkájuk. Zoltán vállalkozása több család ot tartott el, míg Dianának 100 beosztottja volt egy multinacionális cégnél. A rájuk nehezedő nyomás és az ezzel járó feszültség következtében állapotromlástól tartottak és ez Zoltán esetében már az interjú készítésekor jelentkezett is.

\section{3. faktor: jól-lét}

Ebben a faktorban az érzelmi, testi és anyagi jólét jelenik meg. Mivel a pszichiátriai betegnek diagnosztizáltak életében, ha időszakosan is, de kiemelt szerepet játszik az egészségügyi ellátás, ezért erre itt részletesebben kitérek. A pszichiátriai diagnózissal való első szembesülés, a kórházi tapasztalatok mind-mind jelentősen meghatározzák az érintettek énképét, önbecsülését. Maga a diagnózis is stigmává válhat, nem csak a környezet, hanem az érintett számára is (másodlagos stigma). 


\section{TEMATIKUS TANULMÁNYOK - Pszi-komplexum}

\section{1. eset - Zoltán}

Zoltán életében a drogok és az alkohol hatására egy olyan élethelyzet állt elő, ami külső beavatkozást igényelt. Zoltán ezzel tisztában volt, ahogy a pszichiáterek fogalmaznak, volt betegségtudata.

„Én felhívtam még egy jó pár top pszichológust mindegyik 3-4 hónapot mondott. De talán nem is baj. Az összes beteg, aki körülöttem volt, nagyon irigyelt, hogy nekem egy olyan doki jutott, aki rezidens még, fiatal a szakmában, még nincs kiégve, csak a Lipóton tanul és nincs magánpraxisa. Mert más betegnek jutott 5 perc a dokijával futtában, nekem pedig napi egy óra." (49 éves férfi)

Zoltán bekerült az OPNI-ba, majd néhány hét múlva a pszichiátere hazaküldte. Bipoláris depresszió diagnózist kapott, erős gyógyszereket szedett, de a pszichiátere segítségével 2 év után elhagyta ezeket, és már csak egy gyógyszert szed. Jelenleg is ugyanehhez az orvoshoz jár, de már nem az OPNI-ba. Viszonyukkal Zoltán elégedettnek tűnik.

„A pszichiáteremhez úgy járok, hogy a vállalkozásról beszélgetünk, hol voltak hétvégén, mi hol voltunk, mit föztem, hova megyünk, milyen az idő, szóval semmi. Felírja a gyógyszert és kész. Ha gyorsabban megyek, vagy többet kérek, akkor megkérdezi mi történt? És akkor elmondom. Hát nem jó Zoltán, hogy így van, nem írok fel adagolást, úgyis úgy szedi, ahogy akarja, szedje ambulánsan, ahogy érzi, ez így is van." (49 éves férfi)

A szenvedélybetegségek és a pszichiátriai diagnózis úgy tűnt az élettörténetének szerves részét képezi, identitásának meghatározó eleme, de nem tekint magára betegként.

„Nyilván rengeteg mindennek az oka az alkohol, a kábítószer, ráment a házasságom, ráment az egészségem, ráment az egzisztenciám, úgymond minden, de a vérképeim és a 13 év kitartása, a vérképemböl tisztán látszik, hogy visszaállt minden szervezetileg. Nem vagyok rá büszke, de bárkivel megtörténhet, arra meg, hogy mániás depresszió, azzal meg mit kezdjünk. A válasz az, hogy igazából nem foglalkozom vele, nincs jelen a napjaimban, óráimban, egyáltalán nem foglalkozom vele." (49 éves férfi)

Az interjú idején Zoltán családi állapota kiegyensúlyozott volt, lakhatási körülményei is és anyagi helyzete is, bár ő maga utalt rá, hogy mostanában a vállalkozásában problémák vannak, amik negatívan befolyásolják egészségi állapotát, kevesebb ideje van családjára, pihenésre, feltöltődésre. 


\section{TEMATIKUS TANULMÁNYOK - Pszi-komplexum}

„Tehát én vagyok a megoldó, a likviditás, hogy mikor hol mit, ezeket én fogom össze és nagy felelösség, rengeteg ember dolgozik nem mellettem, hanem velem együtt 80-10 család. Nem beszélve a sajátunkról, ami a legfontosabb. Most autóink vannak, ingatlanjaink vannak, utazásaink voltak komolyak, tudunk menni jobbra-balra amoda, vannak nagyon okos telefonjaink, amire szükségünk is van" (49 éves férfi)

\section{2. eset}

Diana életminőségét befolyásolja, a testi jóllétének bizonytalansága, mely az evési zavarai miatt kiemelkedő jelentőségűek. A tápálkozási zavar súlyos fiziológiai hatásainak következményeként 19 évesen került először kórházba.

„Lejár a BNO kezelési idő, kezelési napok száma és aztán egyszerüen elbocsájtanak. Folytatódott ugyanott. Aztán egy idő után visszakerülsz. Általában az ilyen embereket leírják." (37 éves nő)

Diana öngyilkossági kísérletei miatt többször volt kórházban is.

„Ott zárt osztályra kerültem, ami úgy nézett ki egy kezelés, hogy lebilincseltek egy ágyhoz, időnként beléd tömtek egy bizonyos mennyiségü gyógyszert, majd elvittek egy úgy nevezett múvészeti terápiára, ahol közölték, hogy rajzoljam le ezt a cserép virágot. De igazából azt, hogy megpróbálja megérteni, hogy mi okozza, hogy én ilyen állapotban vagyok, hogy hogyan lehetne megküzdési stratégiákat tanítani, vagy olyan csoportterápiát vagy egyéni terápiát, vagy alternatívát kínálni, hogy nem érzi” (37 éves nő)

Diana munkahelyi karrierje, mint korábban volt róla szó, egy sikertörténet, de ahogy az általában lenni szokott, de Diana elmeséli ennek árnyoldalait is.

„A munka az rettenetes nagy teher, jobbrészt ilyen szervezeti problémák miatt, a cég jellegéböl és hibáiból adódik, mert nagyon nehezen tudom elviselni, ha valami nem tökéletes, ha nem tudok 100 \%-ot nyújtani valami miatt. Tehát a férjem nagyon jól tudja, nagyon jól ráérzett, hogyha nekem nincs lefoglalva a lehetö legtöbb agykapacitásom, akkor mindig rosszabb állapotban vagyok lelkileg. Ha én nem pöröghetek 120 \%-on akkor én rosszul érzem magam." (37 éves nő)

„Most előléptettek, lány manager, középszinten voltam, és most felkértek, hogy csináljak egy új részleget a cégen belül, még van potenciál, és ez nem a vége, úgy néz ki, hogy sikerül áttörni az üvegplafont vagy elég eröteljesen repedezik, igazából rettenetesen jó vagyok abban, amit csinálok" (37 éves nő) 


\title{
TEMATIKUS TANULMÁNYOK - Pszi-komplexum
}

Azonban Diana életében is megmaradtak a mentális zavar tünetei, az evési zavarokat nem sikerült leküzdenie.

\begin{abstract}
„Amikor semmit nem tudsz kontrollálni, csak a saját testedet, akkor egész egyszerüen arra koncentrálod az energiádat, hogy legalább ezt tudod uralni. Ez egy nagyon érdekes dolog egyébként és az a legdurvább, hogy általában az evészavar fiatal emberekre jellemző, fiatalabb korosztályra, és ez nekem a mai napig megmaradt. És nem feltétlenül úgy kell értelmezni, hogy egy nagyon súlyos életveszélyes állapot, de mikor az embernek különleges szokásai vannak az étkezéssel kapcsolatban, mindenképpen valamilyen étkezési zavarnak nevezhető. Nem szeretek másokkal együtt enni, nyilvános helyen enni. Rettenetesen gyorsan eszem, két perc alatt eltüntetem az ételt." (37 éves nő)
\end{abstract}

Az interjúk interpretálásakor számos nehézségbe ütköztem, mert szerettem volna az életút mentén illusztrálni az életminőség egyes faktorait. Azonban az egyes faktorokat nehéz különválasztani, az önállóság és a társadalmi részvétel egyes területei mind-mind kihatnak az általános jól-lét érzelmi, testi területeire. Az általam bemutatott interjúalanyoknak sikerült személyes képességeiket kibontakoztatniuk, amit kamatoztatni tudtak a munkaerőpiacon, így anyagi jól-létükkel elégedettek. Bár az interjú készítésekor a testi és érzelmi jól-léttel kapcsolatosan nem tudtak egyértelműen pozitívan nyilatkozni. A múltban szerzett tapasztalataik, a fiatal felnőttkori szélsőséges mentális állapotromlások következtében szinte sosem érzik magukat biztonságban, saját maguknak kellett tudatosan kialakítani egy olyan stratégiát, mellyel a lehető legkiegyensúlyozottabb életet tudják élni. Ez a teher és ez az állapotromlástól való félelem mindig jelen van életükben, és míg Zoltánnak van élettársa és hivatalos külső kontrollja a kezelőorvosa személyében, addig Diana csak a férjére számíthat.

\section{Összegzés}

A kvantitatív adatok alapján megállapítható, hogy az akadályozottsággal élők életminősége általában rosszabbnak mondható azokénál, akik egészségi állapotuk miatt nem érzik akadályozottnak magukat. Feltehetően itt olyan élethelyzetek jelentek meg, melyek eleve depriváltak; alacsonyabb iskolai és szocioökonómiai státus mellett, vagy éppen okaként, nem kielégítő egészségi állapot társult. Ezekben az esetekben a kvantitatív adatok jellegéből adódóan nem eldönthető, hogy melyik tényező az ok és melyik a következmény. Az akadályozottsággal és az akadályozottság nélkül élők esetében a legmarkánsabb eltérés a szubjektív jól-lét érzelmi, hangulati faktorábán jelentkezik, az akadályozottsággal élők körében jóval magasabb azoknak az aránya, akik magányosnak, levertnek, szomorúnak érzik magukat. 


\section{TEMATIKUS TANULMÁNYOK - Pszi-komplexum}

A kvalitatív elemzésben bemutatott két interjúalany életminősége az ESS adatok akadályozottsággal élő népesség életminőségéhez viszonyítva kifejezetten jónak tűnik: mindkettőjük családban él, dolgozik, elégedett anyagi helyzetével, úgy érzik átestek egy nagyon súlyos krízisen, amelyből megtalálták a kiutat. Ehhez az egyik esetben hozzájárult az egészségügyi rendszer, míg a másik esetben inkább hátráltatta a felépülést. Mindkét interjúalany életében a személyes viszonyok, a kapcsolatháló által elérhető támogatások, illetve az, hogy lehetőségük van saját képességek kibontakoztatásához, járultak hozzá ahhoz, hogy elkerüljék az újabb krízishelyzetet. Azonban ők maguk is megfogalmazták, hogy a korábbi pszichiátriai krízisnek vannak viselkedésbeli és egészségükre ható maradványtünetei és bizonyos szinten ezek nehézséget vagy akadályt jelentenek nekik, amikkel nap, mint nap szembesülnek. Kialakítottak a környezetükkel kölcsönhatásban egy egyensúlyt, azonban ezek kényes és bizonytalan egyensúlyok, és kérdéses, hogy a támogató közeg nélkül fenntartható-e.

\section{Irodalom}

Becker, M. - Diamond, R. J. (2006): Quality of Life Measurement in Persons with Schizophrenia: Are We Measuring what's Important? Mental Health Law \& Policy, University of South Florida, 111-126.

http://scholarcommons.usf.edu/cgi/viewcontent.cgi?article=1236\&context=mhlp_facpub (utolsó letöltés dátuma: 2019. április 21.)

Görög K. (2005): Funkcionalitás/funkciócsökkenés - Kutatási Jelentés, Országos Lakossági Egészségfelmérés. Országos Epidemiológiai Központ, Budapest

Hammell, K. W. (2004): Exploring quality of life following high spinal cord injury: a review and critique. Spinal Cord 42, p. 491-502

https://www.nature.com/articles/3101636 (utolsó letöltés dátuma: 2019. április 21.)

Kováts A. - Tausz K. (1997): Gyorsjelentés a fogyatékos emberek helyzetéről. Szociális Szakmai Szövetség, Budapest

Központi Statisztikai Hivatal (2013): 2011. Évi Népszámlálás 3. Országos adatok. Budapest, KSH

Kullmann, L. (2009): A rehabilitáció korszerű szemlélete. „A funkcióképesség, fogyatékosság és egészség nemzetközi osztályozása” (FNO), mint a holisztikus látásmód nemzetközileg elfogadott szabálya. In: Nagyné Zölde M. (szerk.): Szöveggyưjtemény - A munkaképesség szociális, (gyógy)pedagógiai, foglalkoztathatósági szempontú minősítéséhez. Budapest, ELTE BGyF, p. 9-13 http://e-oktatas.barczi.hu/extra/tudasbazis/szoveggy/szgy_zolde.pdf (utolsó letöltés: 2014. 04. 30) 


\section{TEMATIKUS TANULMÁNYOK - Pszi-komplexum}

Martinez-Martin P. - Jeukens-Visser M. - Lyons K. E. - Rodriguez-Blazquez C. - Selai C. - Siderowf A. - Welsh M. - Poewe W. - Rascol O. - Sampaio C. - Stebbins G. T. - Goetz C. G. - Schrag A. (2011): Health-Related Quality-of-Life Scales in Parkinson's Disease. Critique and Recommendations Movement Disorders, Vol. 26, No. 13, p. 2371-2380

https://www.movementdisorders.org/MDS-Files1/PDFs/Task-Force-Papers/ Health_Related_QoL.pdf (utolsó letöltés dátuma: 2019. április 21.)

Morris F. - Vandemaele E. - Claes L. - Vandevelde, S. (2013): Quality of Life in Persons with Intellectual Disabilities and Mental Health Problems: An Explorative Study. Scientific World Journal. 2013: 491918. doi:10.1155/2013/491918 https://www.ncbi.nlm.nih.gov/pmc/articles/PMC3576796/ (utolsó letöltés dátuma: 2019. április 21.)

Noll, H. H. (2004): Social Indicators and Quality of Life Research: Background, Achievements and Current Trends. Advances in sociological knowledge, Springer $\mathrm{p}$. 151-181

https://www.researchgate.net/profile/Heinz-Herbert_Noll/publication/ 257940809_Social_Indicators_and_Quality_of_Life_Research_Background_Achievements_and_Current_Trends/links/004635266492e06790000000.pdf (utolsó letöltés dátuma: 2019. április 21.)

OECD (2012): Sick on the Job? Myths and Realities about Mental Health and Work, Mental Health and Work. OECD Publishing http://dx.doi.org/10.1787/9789264124523-en (utolsó letöltés dátuma: 2019. április 21.)

Rapley, M. (2003): Quality of Life Research: A Critical Introduction. London, Sage

Schalock, R. L. - Brown, I. - Brown, R. - Cummins, R. A. - Felce, D. - Matikka, L. - Keith, K. D. - Parmenter, T. (2002): Conceptualization, Measurement and Application of Quality of Life for Persons With Intellectual Disabilities: Report of an International Panel of Experts. Mental retardation, Vol. 40. Number 6., p. 457-470. https://pdfs.semanticscholar.org/e542/e17038b0ab3f3be8d10f1b3744cda0e9906d.pdf (utolsó letöltés dátuma: 2019. április 21.)

Schalock, R. L. - Verdugo, M. A. A. (2002): Handbook on Quality of Life for Human Service Practitioners. Washington, American Association on Mental Retardation https://s3.amazonaws.com/academia.edu.documents/11362719/bookchapterexcerpt5chandbk_human_service.pdf?AWSAccessKeyId=AKIAIWOWYYGZ2Y53UL3A\&Expires=1533837467\&Signature $=\mathrm{eJ} \% 2$ FK80EZSYF2nFROng1nHK\%2FXeSw\%3D\&response-content-disposition=inline\%3B\%20filename\%3DHandbook_on_quality_of_life_for_human_se.pdf (utolsó letöltés dátuma: 2019. április 21.) 
www. metszetek.unideb.hu

\section{TEMATIKUS TANULMÁNYOK - Pszi-komplexum}

Vályi R. (2008): Az altruizmus jelensége a társadalomtudományban. In: Kötő-Jelek, ELTE TáTK Szociológia Doktori Iskola, Budapest

http://www.tarsadalomkutatas.hu/kkk.php?TPUBL-A-833/kotojelek2007 / TPUBL-A-833.pdf (utolsó letöltés dátuma: 2019. április 21.)

2013. évi LXII. törvény a fogyatékos személyek jogairól és esélyegyenlőségük biztosításáról szóló 1998. évi XXVI. törvény módosításáról

https://mkogy.jogtar.hu/jogszabaly?docid=A1300062.TV (utolsó letöltés dátuma: 2019. április 21.) 